\title{
Multiproxy response to climate- and human-driven changes in a remote lake of southern Patagonia (Laguna Las Vizcachas, Argentina) during the last $1.6 \mathrm{kyr}$
}

Flavia A. Quintana, Nora I. Maidana, Luciana Motta, Julieta Massaferro

Flavia A. Quintana

flavia_quintana@hotmail.com

\section{Luciana Motta}

Julieta Massaferro

CENAC/APN - CONICET. Fagnano 244, 8400 Bariloche, Argentina.

\section{Nora I. Maidana}

DBBE, FCEyN-UBA/CONICET. C. Univer-

sitaria, Pab. 2. Buenos Aires, Argentina.

BOL. SOC. GEOL. MEX. 2018

VOL. 70 NO. 1

P. $173-186$

http://dx.doi.org/10.18268/BSGM2018v70nla10

\section{ABSTRACT}

Laguna Las Vizcachas is a remote lake located in the southern Patagonian steppe east of the Andes, in a key area to study the effects of the climate, especially the mode and intensity of the mid-latitude westerlies which are the dominant climate drivers in this region. Pollen, diatom and chironomid records combined with sedimentological and geochemical data are used to reconstruct the environmental history of Laguna Las Vizcachas (50 $42^{\prime}$ S; $71^{\circ} 59^{\prime}$ W; 1100 masl) from AD 400 to the present. Our results provide evidence of changing climate conditions during the last 1.6 kyr. From AD 400 to 1550 , the presence of Poaceae pollen together with planktonic and small benthic diatoms suggests a gradual increase in precipitation, and persistent cold air temperatures. At $c a$. AD 1550, the decrease in Poaceae and the high values of small benthic diatoms are interpreted as colder temperatures, which agree with nearby records of glacial advances probably associated with the Little Ice Age. The simultaneous appearance of the cold-tolerant chironomid morpho taxa Tanytarsini supports this assumption. From AD 1750 to the present, the appearance of Ranunculaceae-type pollen, semi-terrestrial and littoral chironomids and epiphytic diatoms suggest the expansion of littoral habitats indicative of lower lake levels; which implies less precipitation than previously. Additionally, the increase of both planktonic diatoms Dicostella and Aulacoseira and the sharp decrease of small benthic diatoms is interpreted as the onset of a warming period. The appearance of Rumex and Plantago pollen is related to the arrival of Europeans and subsequent increasing human activity in the area.

Key words: pollen, chironomids, diatoms, climatic variability, last two millennia, southern Patagonia.

\section{RESUMEN}

Laguna Las Vizcachas es un lago remoto situado en la estepa de la Patagonia meridional al este de los Andes, en una zona clave para estudiar efectos del clima, especialmente por el modo y la intensidad de los vientos del oeste (westerlies), que constituyen el factor climático dominante en la región. En este trabajo se utilizaron registros sedimentarios de polen, diatomeas y quironómidos, combinados con datos sedimentológicos y geoquímicos para reconstruir la historia ambiental de Laguna Las Vizcachas (5042' S; 71 $59^{\circ}$ W; 1100 msnm), desde AD 400 hasta el presente. Nuestros resultados proporcionan evidencia de variabilidad climática $d u$ rante los últimos $A D 1600$. Entre los $A D 400$ a AD 1550, la presencia de polen de Poaceae junto con diatomeas planctónicas y pequeñas diatomeas bentónicas, sugiere un aumento gradual de la precipitación con temperaturas del aire frías y persistentes. Alrededor de los AD 1550, la disminución de Poaceae y el aumento de diatomeas bentónicas sugieren temperaturas aún más frías, lo cual es concordante con registros de avances glaciarios en la zona, probablemente asociados a la Pequeña Edad de Hielo. La aparición simultánea de morfotaxa de quironómidos indicadores de temperaturas frías como los Tanytarsini, apoya esta interpretación. Desde el año AD 1750 hasta el presente, la aparición de polen tipo Ranunculaceae, de quironómidos semi-terrestres y litorales y además de diatomeas epifitas sugieren la expansión de hábitats litorales que indican un descenso en el nivel de agua del lago, con menor precipitación que los años previos. Además, el aumento de las diatomeas planctónicas, Dicostella y Aulacoseira, y la fuerte disminución de pequeñas diatomeas bentónicas revelarían el inicio de un periodo de calentamiento. Por último, la aparición de polen de Rumex y Plantago se relaciona con la llegada temprana de los europeos y el posterior aumento de la actividad humana en la zona.

Palabras clave: polen, quironómidos, diatomeas, variabilidad climática, últimos dos milenios, $\mathrm{Pa}$ tagonia sur. 


\section{Introduction}

Southern South America is a key region for the understanding of Southern Hemisphere past environmental variability: it is the only land mass present at this latitude, containing continuous sedimentary records suitable for paleoenvironmental reconstructions. However, there is a limited number of suitable resolved paleorecords (Bonisegna et al., 2009), particularly those covering the last two millennia. This period is fundamental to place modern trends of observed biological proxy patterns, climate variables (mainly temperature and precipitation) and human impact records into a longer-term context to assess earth system sensitivity to natural and anthropogenic pressure. In the last few years, there has been an ongoing debate about placing the start of human activity in geological sequences. It has been proposed that a new epoch, the Anthropocene, has begun and efforts to formalize it are being carried out. It would be a new interval of geological time in which human influence on Earth and its geological record dominate over natural processes (Zalasiewicz et al., 2016). Comprehensive high-quality data sets and a sound understanding of past dynamics at different temporal scales are critical to reducing the uncertainty about the magnitude and impact of current and future climate variability and human activity. Tree rings and glacial records from the southern Patagonian Andes (Stine, 1994; Villalba, 1994; Masiokas et al., 2009a) indicate the occurrence of century-scale climatic fluctuations that can be associated with well-known climatic events in the Northern Hemisphere: the Medieval Climate Anomaly (MCA) and the Little Ice Age (LIA). In the Northern Hemisphere, mean annual temperatures were warmer for the period from AD 800 to 1400 compared to the periods from $\mathrm{AD} 200$ to 800 and from AD 1400 to 1900 Jones and Mann, 2004). However, such climate events have not been well identified in southern South America (Moy et al., 2009). One reason is the sensitivity of proxies to detect the timing, magnitude, and nature of these events. Luckman and Villalba (2001) found a broad synchronicity in the initiation and timing of the LIA when studying glacier advances and treering records along the Andes. However, the study showed considerable variability among sites in both the relative magnitude and date of the events as well as the age of the LIA maximum position. Another possibility for the lack of MCA and LIA signals could be attributed to the paucity of multiproxy records analyzed for this time period in southern South America, which in turn impedes the proper characterization of these climate variations. Recent studies performed in extra-Andean lakes (Markgraf et al., 2003; Haberzettl et al., 2007; Fey et al., 2009; Kastner et al., 2010; Massaferro et al., 2013) revealed that multiproxy analyses of lacustrine sediments constitute a promising strategy for reconstructing past responses of these systems to climate and non-climate changes.

Bioproxy-based reconstructions from Patagonian lakes and peat bogs covering the last two millennia, focused on the dynamics of natural and anthropogenic forest disturbances (Szeicz et al., 1998, 2003; Huber and Markgraf, 2003). Only a few bioproxy-based reconstructions tackled climatic variability (Haberzettl et al., 2005; Mancini, 2007, 2009; Moy et al., 2008). Pollen records from Cabo Vírgenes collected from both a mire and a soil profile (Figure 1) suggested drier than present conditions before AD 800-1000, changing to more humid conditions during the last 700 years (Mancini, 2007). The multiproxy record of Laguna Potrok Aike (Figure 1) (Haberzettl et al., 2005) indicated arid conditions during AD 1250-1410 shifting to wetter and colder conditions until AD 1940. Since AD 1940, hydrological proxies point to persistent dry conditions, while for pollen spectra it is difficult to differentiate climatic variability from human impact (Haberzettl et al., 2005). These records are representative for continental lowlands at the southeastern tip of Patagonia, which are influenced by westerly winds as well as Atlantic and Antarctic circulation patterns. Toward the Andes Mountains and under a stronger influence of westerly winds, the isotopic record of Lago Guanaco (Figure 1) suggests high evaporation for the 
periods AD 1050-1350 and AD 1550-1900. In the same record, pollen trends between AD 1500 and 1800 were interpreted as indicative of higher than present precipitation (Moy et al., 2008; Moreno et al., 2009).

The aim of the present study is to reconstruct the environmental history of Laguna Las Vizcachas, located on the basaltic plateau Meseta de Las Vizcachas at 1100 masl in the Andean Patagonian steppe. High elevation lakes such as Laguna Las Vizcachas (Figure 1) are ideal for this type of study because signals of temperature fluctuations are often amplified by altitude (Fey et al., 2009). The environmental reconstruction is based on terrestrial (pollen) and aquatic (diatoms and chironomids) bioproxy data, complemented with sedimentological and geochemical records from the same sediment sequence (Fey et al., 2009). We aim to evaluate the extent of the sensitivity of these bioproxies to short-term climate variability and to human disturbances over the last millennia.

\subsection{ENVIRONMENTAL SETTINGS}

Laguna Las Vizcachas $\left(50^{\circ} 42^{\prime} \mathrm{S}, 71^{\circ} 59^{\prime} \mathrm{W}\right)$ is located about $70 \mathrm{~km}$ east of the Andean mountain range, in the southern part of the Santa Cruz Province, Argentina (Figure 1). It is a glacial cirque lake situated about 1100 masl surrounded by the basaltic plateau Meseta de las Vizcachas, which reaches elevations of 1400 masl At present, the lake is $18.7 \mathrm{~m}$ deep and has a maximum length (north to south) of $1300 \mathrm{~m}$ and a maximum width of $500 \mathrm{~m}$ (west to east). It has an inflow in form of a waterfall and an outflow at the southern shore (Figure 1). A more detailed geological and geo-

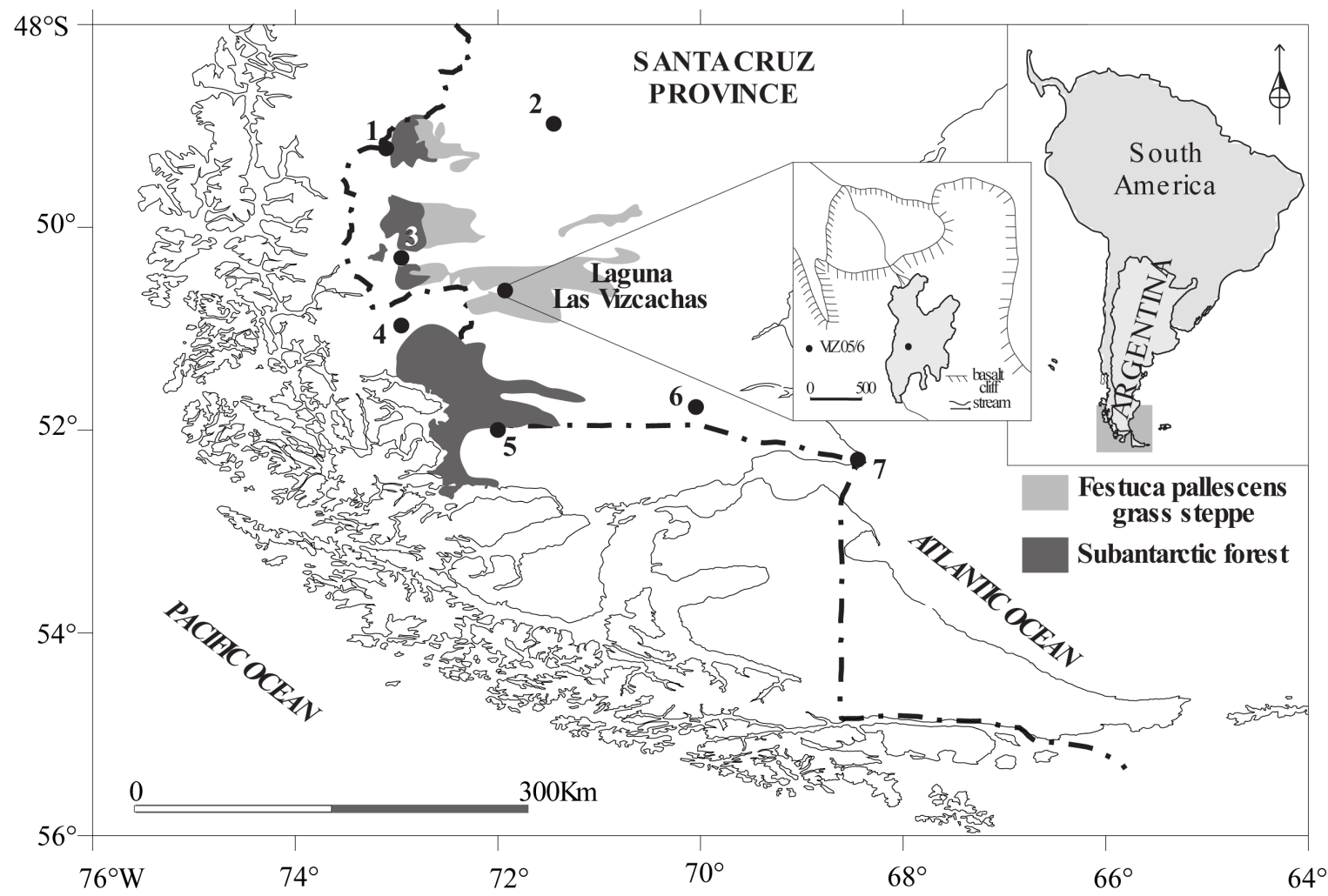

Figure 1 Study area in southern South America and locations mentioned in the text. 1: Northeastern margin of the South Patagonian Icefield (Masiokas et al., 2009a). 2: LagoCardiel ( 600 masl, Stine, 1994). 3: LagoArgentino ( 200 masl, Stine, 1994). 4: Lago Guanaco ( 185 masl, Moy et al., 2008). 5: Rio Rubens bog (220 masl; Huber and Markgraf, 2003). 6: Laguna Potrok Aike (120 masl, Haberzettl, 2005). 7: Cabo Vírgenes (70 masl, Mancini, 2007). Main vegetation units modified from Gonzalez and Rial (2004). Dashed line represents the international limit between Chile and Argentina. 
morphological description of the catchment area was presented by Fey et al. (2009).

The climate is determined by the intensity of the southern westerly winds throughout the year. The Andean mountain range represents a barrier for humid air masses coming from the west Pacific, leading to a pronounced precipitation gradient from $3000 \mathrm{~mm}$ along the western slopes to 200 $\mathrm{mm}$ in the eastern lowlands. Meseta Las Vizcachas, close to the Andes and above 1000 masl, is located along this precipitation gradient. The annual rainfall at Laguna Las Vizcachas is $c a .300$ $\mathrm{mm}$, and the mean annual temperature is between 4 and $6.5^{\circ} \mathrm{C}$. In July the average temperature is below $0^{\circ} \mathrm{C}$, indicating precipitation in the form of snow is common during winter.

The dominant vegetation at this latitude is Festuca pallescens grass steppe which is present as isolated grass patches on highlands above 700 masl. This steppe is characterized by a high diversity of dwarf shrubs or cushions like Nassauvia darwinii, Mulinum microphyllum and Nardophyllum obtusifolium. Herbs are represented by Carex argentina, C. andina, Armeria elongata, Calceolaria lanceolada, Acaena pinnatifida, Relbunium richardianum, Polygala darwiniana, Colobanthus lycopodioides and Perezia recurvata (León et al., 1998, Oliva et al., 2001). At Laguna Las Vizcachas the presence of the cushion-plant Empetrum rubrum is meaningful. This species is common in cold highlands and slopes with long snow periods and at lower altitudes, on acidic soils with little nutrients and high availability of aluminum (Pisano, 1977; Roig et al., 1985).

\section{Methods}

\subsection{SAMPLING, LITHOLOGY, GHRONOLOGY, AND PREVIOUS GEOGHEMIGAL ANALYSIS}

In March 2005, a sediment core (VIZ05/6) of 83 $\mathrm{cm}$ was recovered in the central part of the lake at $16 \mathrm{~m}$ depth with a modified ETH-gravity corer (Kelts et al., 1986) (Figure 1). The chronology, physical properties, mineralogy, stable isotopes, geochemistry, and general trends of diatoms of this core were studied by Fey et al. (2009). In the following paragraphs we briefly describe the methodology applied in this study.

The sediment sequence was divided into three lithological units: Unit A $(83-70 \mathrm{~cm})$, contains a plant macro-remain layer at the bottom. Unit B (70-25 $\mathrm{cm})$ consists of many dark layers. Unit $\mathrm{G}(25-0$ $\mathrm{cm})$ presents several plant macro-remain layers at different levels $(25-23 \mathrm{~cm}, 16.5-13 \mathrm{~cm}, 8.5-7.5$ $\mathrm{cm}, 5.5-4.5 \mathrm{~cm}$ and $1.5-0.5 \mathrm{~cm})$. Seven samples of fine fraction $(<100 \mu \mathrm{m})$ of bulk sediment were dated at the Poznań Radiocarbon Laboratory, Poland. AMS ${ }^{14} \mathrm{C}$ dates were calibrated with the southern hemisphere calibration curve (SHCal04, McCormac et al., 2004) using the software CALIB 5.0.2 (Stuiver and Reimer, 1993; Stuiver et al, 2005). Ages for sediments below the lowermost AMS ${ }^{14} \mathrm{C}$ date were estimated by extrapolation of sedimentation rates. More details about the agedepth model were published in Fey et al. (2009). Volume specific magnetic susceptibility $(\kappa)$ was measured with a Bartington F-sensor. The mineralogical composition was determined by standard powder X-ray diffraction (XRD) analyses (Philips X'Pert Pro MD equipped with an X'Celerator Detector Array). Concentrations of total organic carbon (TOC) and total nitrogen (TN), among others, were determined with a CNS elemental analyzer (EuroEA, Eurovector). Biogenic silica (BiSi) was analyzed by applying an alkaline digestion in autoclaves and subsequent detection by a continuous flow system with UV-VIS spectroscopy.

\subsection{BIOPROXY ANALYSIS}

A sediment sample of $4 \mathrm{~cm}^{3}$ was taken every centimeter along the core. Each sample was divided and approximately $1 \mathrm{~cm}^{3}$ of sediment was assigned for pollen, $1 \mathrm{~cm}^{3}$ for diatom analyses and 2 $\mathrm{cm}^{3}$ for chironomids. These proxies constitute the original data supplied for the current study.

Each pollen sample was submerged in $\mathrm{KOH}$ overnight to remove humic acids and then sieved through a $125 \mu \mathrm{m}$ mesh. Only the fraction $<125 \mu \mathrm{m}$ was chemically treated. Exotic Lycopodium tablets of a known concentration were added in order to 
calculate pollen concentration (Stockmarr, 1971). Procedures included the treatment with $10 \% \mathrm{HCl}$ for dissolution of carbonates, $40 \% \mathrm{HF}$ for silica removal and acetolysis for cellulose removal (Faegri and Iversen, 1989). The residues were mounted on slides and counted under the microscope at $1000 \times$ until a pollen sum of 300 per sample was reached. The analysis was performed every $4 \mathrm{~cm}$ of depth. Pollen percentage is based on the sum of all pollen types identified. Algal microfossils like Botryococcus and Pediastrum were also counted in the pollen slides. Reference pollen samples and the pollen floras of Heusser (1971) and Markgraf and D'Antoni (1978) were employed to facilitate pollen identification. Diatoms samples were treated following standard procedures, including heating with $\mathrm{H}_{2} \mathrm{O}_{2}$ (Battarbee, 1986) and mounting permanently onto microscope slides using Naphrax ${ }^{\circledR}$ mounting medium. A minimum of 400 valves were counted to calculate relative frequencies. Diatom taxonomy follows the standard literature (Krammer and Lange-Bertalot, 1986, 1988; Simonsen, 1987; Rumrich et al., 2000). A more detailed laboratory procedure is described by Fey et al. (2009). Chironomids samples of $2 \mathrm{~g}$ dry weight were prepared according to Massaferro and Brooks (2002). Sediment was deflocculated using $10 \% \mathrm{KOH}$ and sieved through 100 and $200 \mu \mathrm{m}$ meshes. Material retained by the meshes was hand-picked from a modified Bogorov counting tray under a dissecting microscope at magnifications of 25-40 ×. Individual heads were placed onto microscope slides and mounted using Hydro-Matrix ${ }^{\circledR}$ mounting medium. Identifications were made using a Nikon phase microscope at $400 \times$ magnifications. Head capsules were identified with reference to available taxonomic literature (Cranston, 2000; Massaferro and Brooks, 2002) and the Patagonian subfossil chironomid taxonomic identification guide (Massaferro et al., 2013).

Bioproxies stratigrafic diagrams were elaborated with the C2 software version 1.6.6 (Juggins, 2010).

\section{Results}

Chronology was established from seven AMS ${ }^{14} \mathrm{C}$ ages which gave a basal age of AD 410 (Fey et al., 2009). To facilitate temporal correlation and discussion of changes in the bioproxy records, stratigraphic zones were established following lithological units A (AD 400-750), B (AD 7501750) and $\mathrm{C}$ (AD 1750-2005), described in Fey et al. (2009). Owing to conspicuous changes in the bioproxies at $c a$. AD 1550, unit B was split into two subzones, B1 (AD 750-1550) and B2 (AD 1550-1750). In addition, geochemical data (TOC, TOC/TN, BiSi, Si/Ti) published (Fey et al.,2009) were combined with our data to contrast our interpretations.

\subsection{POLLEN REGORD}

A total of forty pollen types were identified in the sediment core. Major trends are shown in a simplified pollen diagram (Figure 2). The terrestrial vegetation around the lake is represented by the dominance of Poaceae with low values of Acaena, Asteraceae subf. Asteroideae and Empetrum rubrum. Before AD 1550 (units A and B1) the vegetation is dominated by a grass steppe represented by $>40 \%$ of Poaceae values in more than half of the total samples and $c a .3-5 \%$ of the other pollen types mentioned above. In zones B2 and C Poaceae declines fluctuating between 35 and 40\%. Empetrum rubrum is relatively unchanged, although slight increases were recorded at the beginning of zones $\mathrm{B} 2$ and $\mathrm{C}$, and in present times. After AD 1750 (zone C) and until the top of the record, Solanaceae was continuously recorded and Senecio, Rumex, Plantago and Ranunculus-type appeared. The extra-regional pollen of the Nothofagus dombeyi-type is present all along the sequence with percentages of $c a .30 \%$.

\subsection{DIATOM RECORD}

A summary diagram (Figure 3) shows the diatom record dominated by small benthic forms oscillat- 


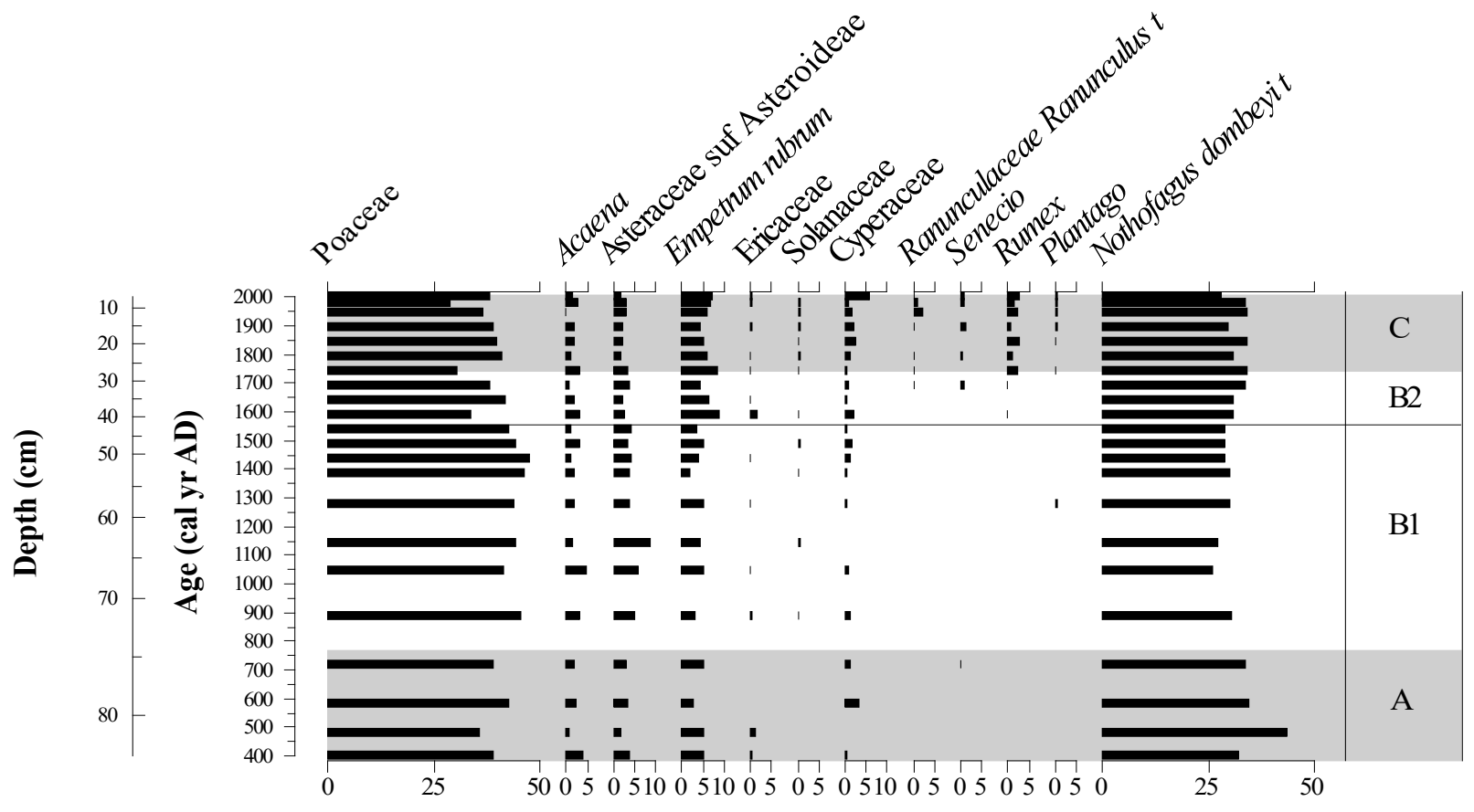

Figure 2 Pollen diagram of selected taxa (all data in percentages).

ing between $c a .40 \%$ to $60 \%$ up to $\mathrm{AD} 1750$ (zones A, B 1 and B2) and decreasing to $20-40 \%$ in zone C. Subdominant planktonic taxa, Aulacoseira distans and Discostella stelligera seem to follow comparable patterns of change, showing an increasing trend in zone $\mathrm{A}$ followed by a decrease in zone $\mathrm{B} 1$ up to $\mathrm{AD} 1500$, where they start to increase again reaching the highest values ( $c a .20 \%$ D. stelligera and $c a$. $40 \%$ A. distans) at $c a$. AD 1700/1750. Both species show a gradual decrease from AD 1700/1750 up to the present. Fluctuating low values of epiphytic taxa Cocconeis placentula, Gomphonema gracile, $G$. sp. aff. subclavatum, and benthic Karayevia clevei are recorded from the bottom of the core up to $\mathrm{AD}$ 1750. At that time, Karayevia clevei increases. After $\mathrm{AD}$ 1750, there is an increase of Gomphonema sp. aff. subclavatum, G. acuminatum, and Epithemia adnata together with the appearance of benthic taxa such as Fragilaria capucina, F. crotonensis, Encyonema minutum, E. silesiacum, and Achnanthidium minutissimum that remain high until present days.

\subsection{GHIRONOMID RECORD}

Chironomids are only present in zones B1, B2 and C (Figure 4) with low abundances values (between 10 and 30 head capsules achieving the maximum values in the last 300 years). From the 6 morphotaxa recorded, Tanytarsini $1 \mathrm{~B}(50 \%$ of the total number) is dominant, followed by Paratrissocladius accuminatus (25\% of the total number) and Cricotopus spp. (8\% of the total number). The remaining taxa (Smittia, Paratrichocladius, and Tanytarsini 1A) are present with abundances of $<5 \%$.

\section{Discussion}

\subsection{ENVIRONMENTAL RECONSTRUCTION}

\subsubsection{PRIOR TO AD 1550}

The almost exclusive dominance of the small benthic diatoms from AD 400 up to 900 suggest long periods of ice cover and persistent cold air 


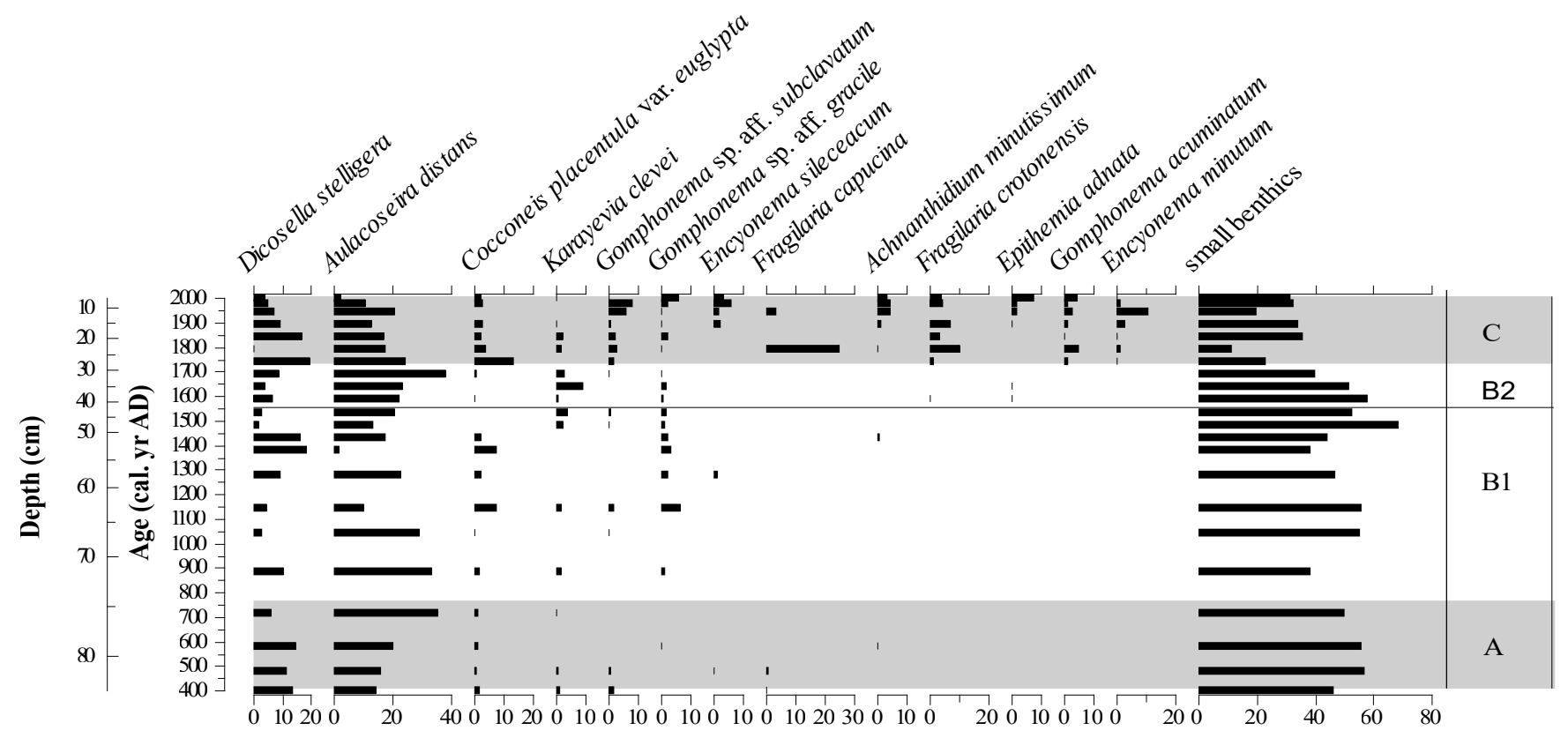

Diatom diagram of selected taxa (all data in percentages).

temperatures compared to the present (Figure 3). Indeed, small benthic diatoms succeed when the ice-free growing season is short (Hobbs et al., 2010). The present winter temperatures in the catchment area of Laguna Las Vizcachas are below $0^{\circ} \mathrm{C}$. Thus it is highly probable that the lake surface was also covered by ice during past cold seasons. Likewise, the low percentages of planktonic diatoms Aulacoseira distans and Discostella stelligera may indicate low stability and mixing of the water-column probably related to strong winds (Michelutti et al., 2015). In Sterken et al. (2008) low abundance of these taxa was interpreted as a depletion of oxygen in the aquatic environment. Indeed, periods of prolonged ice cover on the lake and snow cover in the catchment area may lead to a reduction of the organic matter oxidation due to lake water stratification under ice cover and prolonged anoxic conditions at the sediment/water interface (Fey et al., 2009).

Between AD 800 and 1000 the increase of Aulacoseira distans coupled with the decrease of small benthic diatoms (Figure 3) suggests temperature amelioration. Poaceae values exceeding 40\% from $c a$. AD 900 indicate improved grass devel- opment, hence wetter than present conditions until AD 1550. Ecological studies performed on Festuca pallescens (Poacea) steppes showed that the water availability in the soil, mainly in summer, is a critical factor controlling the establishment and development of these grasses (Bertiller et al., 1996). Therefore, vegetation trends seem to indicate that precipitation began to increase gradually. Between AD 1200 and 1400, high precipitation is suggested by the presence of epiphytic diatoms Cocconeis placentula, Gomphonema spp. and Karayevia clevei which are commonly related to fluvial water (Sterken $e t$ al., 2008). Titanium (Ti), calcium (Ca) and magnetic susceptibility values recorded by that time support our interpretations. They are linked to enhanced fluvial clastic input due to increasing precipitation according to Fey et al. (2009). Summarizing, between AD 400 and AD 1550 cold and mostly wet conditions prevailed in Las Vizcachas environment, although a warm spell may have intercepted this cold trend at $c a$. AD 800 to 1000 . The most likely mechanism causing this surplus in precipitation can be associated with intensification of the westerly wind circulation (Fey et al., 2009). 


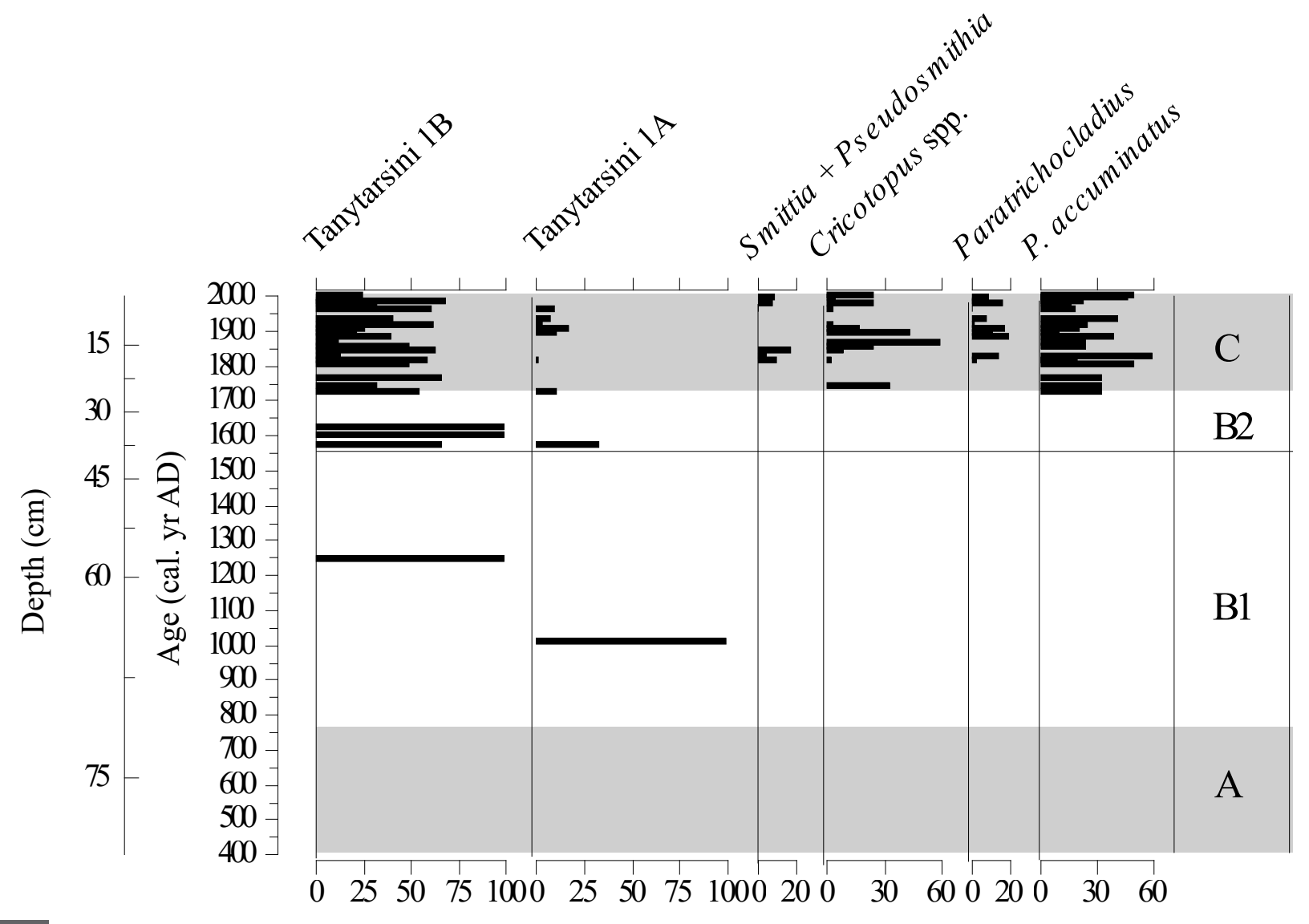

Figure 4 Chironomid diagram of selected taxa (all data in percentages).

Records from different natural archives, like relict tree and shrub stumps rooted in current lakes and marshes of Lago Cardiel $\left(48^{\circ} 57^{\prime} \mathrm{S}, 71^{\circ} 26^{\prime} \mathrm{W}\right)$ and Lago Argentino (Figure 1; 50 28' S, 72 ${ }^{\circ} 58^{\prime} \mathrm{W}$; Stine, 1994) evidence a period of persistent warm and dry conditions around AD 1200 related to the MCA in lowlands located at similar latitudes (Stine, 1994; Haberzettl et al., 2005; Moy et al., 2009). Oxygen isotope-based reconstructions from Lago Guanaco in Chile (Figure 1; 51 ${ }^{\circ} 52^{\prime} \mathrm{S}$, $72^{\circ} 52^{\prime} \mathrm{W}$ ) suggested high evaporation and then aridity, spanning the period AD 1050-1350 (Moy et al., 2009). Further to the east, the multiproxy record from Laguna Potrok Aike (Figure 1) displayed fluctuations indicating also arid conditions during the MCA, at $c a$. 1250-1410 (Haberzettl et al., 2005). Considering these evidences, Fey et al. (2009) proposed that intensified westerly winds might produce higher precipitation at Laguna Las
Vizcachas but dry conditions at lower elevations, especially to the east. Our bioproxy records from Laguna Las Vizcachas support this hypothesis of wet conditions at western high altitudes during this time period.

\subsubsection{FROM AD 1550 TO AD 1750}

A decline of Poaceae pollen and slight increase of Empetrum rubrum values combined with the highest values of small benthic diatoms shortly before $\mathrm{AD}$ 1600 (figs. 2 and 3) point to colder conditions compared to the time period described above, probably related to the LIA. Colder temperatures with precipitation stored as snow for longer periods of time may have limited the water availability and restricted the development of grass, as shown by lower Poaceae percentages. In this scenario, Empetrum rubrum growth would have been favored. The synchronous appearance of cold chirono- 
mids from the Tribe Tanytarsini (Massaferro and Brooks, 2002) in the aquatic environment reinforced this assumption. Changes in pollen, chironomids, and diatoms of Laguna Las Vizcachas during the time interval AD 1500-1600, seem to predate the beginning of the LIA, which was established by the time of glacier advances reconstructed for the Southern Patagonian Ice Field ( AD 1600) (Luckman and Villalba, 2001; Masiokas et al., 2009a, b). However, the multiproxy reconstruction based on stable isotopes and pollen from Lago Guanaco in Chile ( $\left.51^{\circ} 52^{\prime} \mathrm{S}, 72^{\circ} 52^{\prime} \mathrm{W}\right)$ characterized the onset of the LIA period by an intensification of westerly winds and enhanced precipitation across the Andes at AD 1500 (Moy et al., 2008). This lake is located at around the same latitude as Laguna Las Vizcachas but on the other side of the Andes in the same climatic transition zone, where steep environmental gradients play an important role in defining the glacial patterns (Luckman and Villalba, 2001).

\subsubsection{POST AD 1750, THE ANTHROPOCENE}

The most noticeable change in all the proxies of Laguna Las Vizcachas took place in the transition between zone $\mathrm{B} 2$ and $\mathrm{C}$, at AD 1750. This is indicated by the chironomid assemblage composed by semi-terrestrial and littoral morphotaxa (Smittia, Parapsectro cladius, Cricotopus) mixed with profundal morphotaxa such as Tanytarsini. Together with this, the appearance of Ranunculaceae pollen and the explosion of mainly benthic and epiphytic diatom taxa and the increase of macrophyte remains seem to indicate an expansion of littoral zones and, as a consequence, new habitats for the biota. This change is probably associated with the lowering of lake water levels reflecting a decline in water supply. Low magnetic susceptibility values (k) are consistent with this trend (Fig. 5). During this time, the maximum richness and abundance values of chironomids and diatoms are probably the results of a longer ice-free season suggesting better conditions for aquatic biota to colonize and grow. At AD 1800, shorter periods of ice cover and better conditions are also indicated by the increase of Poaceae and the decline of small benthic diatoms
(Fig. 3). In addition, the highest values of Dicostella and Aulacoseira recorded at the beginning of zone $\mathrm{C}$ also suggest warmer conditions than before. Michelutti et al. (2015) attributed the rise of Dicostella and Aulacoseira to recent climate warming, a shorter duration of seasonal ice cover, and enhanced stability of the water-column thermal stratification during the growing season. The authors interpreted the increase in both planktonic taxa as ecological evidence for the onset of the Anthropocene, detectable in many lake sediments of the northern hemisphere. In our record, the presence of these taxa reflects a combined signal of global warming, reduced wind intensity, and lake level changes. Indeed, the appearance of epiphytic diatoms during this period (Figure 3) was ascribed to both, increased wind intensities and better conditions due to macrophyte growth (Fey et al., 2009).

\subsection{LAKE PRODUCTIVITY}

Before AD 1200, TOC/TN values indicate a mixture of aquatic and terrestrial plant material (Figure 5). This ratio is used as a proxy for the contribution of terrestrial plants into the sediments. Values greater than 20 are associated with allochthonous inputs. Our bioproxy records also show wet conditions by that time. Hence, it is plausible that a combined effect of allochthonous input with a consequent dilution of nutrients by the minerogenic input and/or changes in the organic matter preservation could have taken place, explaining to a certain extent the absence of chironomids by that time. From AD 1200 up to the present, increasing TOC and $\mathrm{Si} / \mathrm{Ti}$ values give evidence of increasing aquatic productivity (Figure 5). TOC reflects the balance between organic matter production and decomposition, whereas $\mathrm{Si} / \mathrm{Ti}$ ratio (Figure 5) is an indicator of in situ diatom and chrysophyte productivity as explained in Fey et al. (2009). This trend continues until the present; however, after ca. AD 1750, the establishment of the different biotic communities combined with the increase of TOG and decrease of TOC/TN points towards an increase of Laguna Las Vizcachas autochthonous productivity. These changes agree with the 


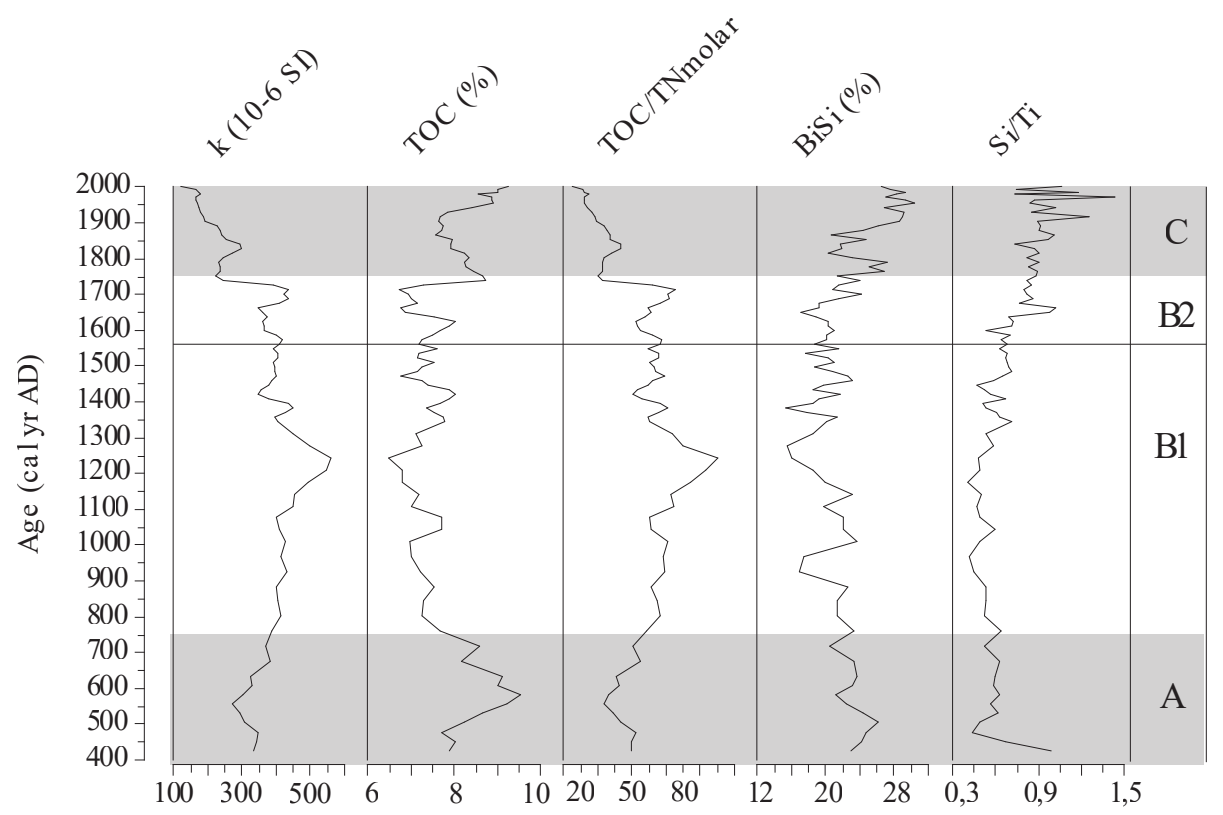

Figure 5 Sedimentological and geochemical proxies after Fey et al. (2009). TOC: total organic carbon; K: volume specific magnetic susceptibility; $\mathrm{Si} / \mathrm{Ti}$ : silica/titanium ratio. TOC/TN: total organic carbon/total nitrogen ratio. Lithological units $\mathrm{A}$ to $\mathrm{C}$ are also shown.

chronology of recent global warming and with the increase of human activities in the area that certainly have contributed to this intensification in the lake trophy.

\subsection{EARLY EUROPEAN SIGNALS AND SUBSEQUENT PERMANENT SETTLEMENTS}

Human activity near Laguna Las Vizcachas is evident from the appearance of Rumex in the pollen record occurring at $c a$. AD 1600, indicating an early presence of European settlers in the area. A first appearance of Rumex dated to $c a$. AD 1620 was also found in the pollen record of Rio Rubens, a bog located south of Laguna Las Vizcachas (Figure 1; 5208'15"S-7 152’53'W; Huber and Markgraf, 2003). Given that Rumex is widely recognized as the stratigraphic marker of the first European settlements in southern Patagonia at the end of the $19^{\text {th }}$ century (Heusser, 2003), the earlier appearance in two different pollen records is remarkable. A continuous presence of exotic Plantago is observed in the pollen record slightly before AD 1900. Some species of Plantago are considered indicators of the presence of Europeans (Heusser, 2003). Coupled with the Rumex record, Plantago pollen type along with the appearance of epiphytic taxa like Achnanthidium minutissimum and Epithemia adnata, in the diatom record, may indicate a permanent settlement of Europeans. Moreover, it can be related to the beginning of rural activities around the lake before AD 1900 and onwards, given that Achnanthidium minutissimum and Epithemia adnata are both associated with mild to moderate eutrophication levels of lakes (Hobbs et al., 2010).

\section{Conclusion}

The combined analysis of pollen, diatoms and chironomids, indicates climatic variations during the last $\sim 1500$ years at Laguna Las Vizcachas. The results also indicate that changes in the biotic communities after AD 1750 are response to human presence in the area. Assuming that water deficit is the most prominent climatic characteristic in Patagonia, Poaceae fluctuations are considered a proxy for air humidity, whereas fluctuations in the abundance of small benthic diatoms were interpreted 
as a proxy for the duration of lake ice-cover. Since $\mathrm{AD} 700$, pollen and diatom taxa coupled with magnetic susceptibility values suggest a period of high precipitation lasting more than 500 years. During this time, temperatures were cold enough to maintain lake surface ice during cold seasons. Such a trend is opposite to reconstructions from Chilean lowland records at similar latitudes, with mimic the MCA dry period (Stine, 1994; Haberzettl et al., 2005; Moy et al., 2009). Pollen, diatom and chironomid records support the hypothesis proposed by Fey et al. (2009) of inverse precipitation regimes between western and eastern parts of extra-Andean southern Patagonia. The coldest conditions are recorded at $c a$. AD 1550 by the increase of Empetrum rubrum and small benthic diatoms. This cold signal registered in Laguna Las Vizcachas precedes the beginning of the LIA, recorded by glacier fluctuations in the Southern Patagonian Ice Field (Masiokas et al., 2009a, b). Before AD 1700, the climate was cold and wet. Therefore, it is likely that the lake experienced prolonged periods of ice cover enabling lake water stratification and subsequent anoxic conditions at the sediment/water interface. Such a situation could affect aquatic biota by reducing their abundances and favoring the development of species tolerant to low oxygen concentration. The decreasing trend of small benthic diatoms after $\mathrm{AD}$ 1700 marks a change towards warmer conditions. An expansion of littoral habitats due to a decrease in precipitation, and hence a lowering of the lake level explains in part the pronounced increase of epiphytic and benthic diatoms, the appearance of chironomids, and the increase of autochthonous productivity. The appearance in the sequence of Rumex and Plantago pollen coeval with Achnanthidium minutissimum and Epithemia adnata diatoms suggest that both, the early human presence and later human activities in the area also contributed to modify terrestrial and aquatic biotic composition at the lake watershed.

Our paleoecological data give evidence that climate and human impacts started in AD 1750 modifying the lake physical structure and biotic composition. Global warming of the $20^{\text {th }}$ century has certainly enhanced the present lake trophic status causing ecological changes in the aquatic communities. Likewise, our study highlights the potential of the multiproxy approach to provide more accurate environmental reconstructions, especially regarding the timing and onset of human activities in conjunction with changing climates and how these two major drivers have interacted to modify aquatic ecosystems in the past. Disentangling both, climate and human driven impacts on aquatic ecosystems, is a key challenge for understanding the onset and nature of the Anthropocene (Mills et al 2017).

\section{Acknowledgements}

The authors would like to express their thanks to the owner of Estancia Las Vizcachas for permitting access to the lake. The staff of INTA Santa Cruz at Río Gallegos is acknowledged for their assistance in organizing the logistics of the field work. This is a contribution to the project "South Argentinean Lake Sediment Archives and modeling" (SALSA) within the framework of the German Climate Research Program DEKLIM (grants 01 LD 0034 and 0035) of the German Federal Ministry of Education and Research (BMBF) and UNMdP EXA 354/06, 431/08. Additional financial support was provided by the German Science Foundation (DFG) in the framework of the Priority Program 'ICDP' (grant ZO 102/5-1, 2, 3) and by the Consejo Nacional de Investigaciones Científicas y Técnicas (CONICET).

\section{References}

Battarbee, R., 1986, Diatoms analysis. Handbook of Holocene palaeoecology and palaeohydrology, John Wiley \& Sons, New York, New York, USA., 570 p. 
Bertiller, M.B., Zaixso, P., Irisarri, M.P., Brevedant, R., 1996, The establishment of Festuca pallescens in arid grasslands in Patagonia (Argentina): the effect of soil water stress: Journal of Arid Environments, 32, 161-171.

Bonisegna, J.A., Argollo, J., Aravena, J.G., Barichivich, J., Christie, D., Ferrero, M.E., Morales, M., 2009, Dendroclimatological reconstructions in South America: a review: Palaeogeography, Palaeoclimatology, Palaeoecology, 281(3), 210-228.

Cranston, P.S., 2000, Electronic Guide to The Chironomidae of Australia, available at $<$ http://chirokey.skullisland.info/> consulted on 2013.

Faegri, K., Iversen, J., 1989, Textbook of pollen analysis, $4^{\text {th }}$. Ed. John Wiley \& Sons, 328 p.

Fey, M., Korr, C., Maidana, N.I., Carrevedo, M. L., Corbella, H., Dietrich, S., Haberzettl, T., Kuhn, G., Lücke, A., Mayr, C., Ohlendorf, C., Paez, M.M., Quintana, F.A., Schäbitz, F., Zolitschka, B., 2009, Palaeoenvironmental changes during the last 1600 years inferred from the sediment record of a cirque lake in southern Patagonia (Laguna Las Vizcachas, Argentina): Palaeogeography, Palaeoclimatology, Palaeoecology, 281, 363-375.

Gonzalez, L., Rial, P., 2004, Guía geográfica interactiva de Santa Cruz: INTA EEA Santa Cruz, 59 p.

Haberzettl, T., Fey, M., Lücke, A., Maidana, N., Mayr, G., Ohlendorf, C., Schäbitz, F., Schleser, G.H., Wille, M., Zolitschka, B., 2005, Climatically induced lake level changes during the last two millennia as reflected in sediments of Laguna Potrok Aike, southern Patagonia (Santa Cruz, Argentina): Journal of Paleolimnology 33, 283-302.

Haberzettl, T., Corbella, C., Fey, M., Janssen, S., Lücke, A., Mayr, C., Ohlendorf, C., Schäbitz, F., Schleser, G.H., Wille, M., Wulf, S., Zolitschka, B., 2007, Late glacial and Holocene wet-dry cycles in southern
Patagonia: chronology, sedimentology and geochemistry of a lacustrine sediment record from Laguna Potrok Aike, Argentina: The Holocene, 17, 297-310.

Heusser, C.J., 1971, Pollen and spores of Chile: Univ. of Arizona Press, Tucson, 167 p.

Heusser, C.J., 2003, Ice Age Southern Andes. A chronicle of paleoecological events: Developments in Quaternary: Science 3, Elsevier, Amsterdam, 240 p.

Hobbs, W.O., Telford, R.J., Birks, H.J.B., Saros, J.E., Hazewinkel, R.R.O., Perren, B.B., SaulnierTalbot, E., Wolfe, A.P., 2010, Quantifying Recent Ecological Changes in Remote Lakes of North America and Greenland Using Sediment Diatom Assemblages: PLoS ONE 5(4): e10026.

Huber, U.M., Markgraf, V., 2003, European impact on fire regimes and vegetation dynamics at the steppe-forest ecotone of southern Patagonia: The Holocene, 13, 567-579.

Jones, P.D., Mann, M.E., 2004, Climate over past millennia: Review of Geophysics, 42, RG2002.

Juggins, S., 2010, C2 Software for Ecological and Palaeoecological Data Analysis and Visualization, Newcastle upon Tyne: University of Newcastle, available at <https:// www.staff.ncl.ac.uk/stephen.juggins/ software/C2Home.htm>, consulted on 2013.

Kastner, S., Enters, D., Ohlendorf, C., Haberzettl, T., Kuhn, G., Lücke, A., Mayr, C., Reyss, J., Wastegård, S., Zolitschka, B., 2010, Reconstructing 2000 years of hydrological variation derived from laminated proglacial sediments of Lago del Desierto at the eastern margin of the South Patagonian Ice Field, Argentina: Global and Planetary Change, 72, 201-214.

Kelts, K., Briegel, U., Ghilardi, K., Hsu, K., 1986, The limnogeology-ETH coring system: Aquatic Sciences - Research Across Boundaries, 48, 104-115. 
Krammer, K., Lange-Bertalot, H., 1986, Süßwasserflora von Mitteleuropa 2: Bacillariophyceae 1, Teil: Naviculaceae. GustavFischer-Verlag, Stuttgart, 876 p.

Krammer, K., Lange-Bertalot, H., 1988, Bacillariophyceae 2, Teil: Bacillariaceae, Epithemiaceae, Surirellaceae, in Ettl, H., Gerloff, J., Heynig, H., Mollenhauer, D., (eds.), Süsswasserflora von Mitteleuropa: Gustav Fischer Verlag. Stuttgart, Germany, 2(2), 1-596.

León, R.J.G., Bran, D., Collantes, M., Paruelo, J.M., Soriano, A., 1998, Grandes unidades de vegetación de la Patagonia extra andina: Ecología Austral, 8, 125-144.

Luckman, B.H., Villalba, R., 2001, Assessing the Synchroneity of Glacier Fluctuations in the Western Cordillera of the Americas During the Last Millennium: Interhemispheric Climate Linkages: Academic Press, San Diego, CA, 119-140.

Mancini, M.V., 2007, Variabilidad climática durante los últimos 1000 años en el área de Cabo Vírgenes, Argentina: Ameghiniana, 44, 173-182.

Mancini, M.V., 2009, Holocene vegetation and climate changes from a peat pollen record of the forest-steppe ecotone, Southwest of Patagonia (Argentina): Quaternary Science Reviews 28(15-16), 1490-1497.

Markgraf, V., D’Antoni, H.L., 1978, Pollen flora of Argentina: Tucson, Arizona, University of Arizona Press viii, 208 p.

Markgraf, V., Bradbury, J.P., Schwalb, A., Burns, S.J., Stern, C., Ariztegui, D., Gilli, A., Anselmetti, F.S., Stine, S., Maidana, N., 2003, Holocene palaeoclimates of southern Patagonia: limnological and environmental history of Lago Cardiel, Argentina: The Holocene, 13, 581-591.

Masiokas, M.H., Luckman, B.H., Villalba, R., Delgado, S., Skvarca, P., Ripalta, A., 2009a, Little Ice Age fluctuations of small glaciers in the Monte Fitz Roy and Lago del Desierto areas, south Patagonian Andes, Argentina: Palaeogeography, Palaeoclimatology, Palaeoecology, 281, 351-362.

Masiokas, M.H. Rivera, A., Espizua, L.E., Villalba, R., Delgado, S., Aravena, J.C., 2009b, Glacier fluctuations in extratropical South America during the past 1000 years: Palaeogeography, Palaeoclimatology, Palaeoecology, 281, 242-268.

Massaferro, J., Ortega, C., Fuentes, R., Araneda, A., 2013, Guia Para la Identificacion de Tanytarsini Subfosiles (Diptera: Chironomidae: Chironominae) de la Patagonia: Ameghiniana, 50(3), 319-334.

Massaferro, J., Brooks, S.J., 2002, Response of chironomids to Late Quaternary environmental change in the Taitao Peninsula, southern Chile: Journal of Quaternary Science, 17, 101-111.

McCormac, F.G., Hogg, A.G., Blackwell, P.G., Buck, C.E., Higham, T.F.G., Reimer, P. J., 2004, SHCal04 Southern Hemisphere Calibration 0-1000 cal BP: Radiocarbon, 46, 1087-1092.

Michelutti, N., Cooke, C.A., Hobbs, W.O., Smol, J.P., 2015, Climate-driven changes in lakes from the Peruvian Andes: Journal of paleolimnology, 54(1), 153-160.

Mills, K, Schillereff, D., Saulnier-Talbot, S., Gell, P., Anderson, J.N., Arnaud, F., Dong, X., Jones, M., McGowan, S., Massaferro, J., Moorhouse, H., Perez, L., Ryves, D.B., 2017, Deciphering long-term records of natural variability and human impact as recorded in lake sediments: a palaeolimnological puzzle: WIREs Water.

Moreno, P.I., Francois, J.P., Villa-Martínez, R., Moy, C.M., 2009, Millennial-scale variability in Southern Hemisphere westerly wind activity over the last 5000 years in SW Patagonia: Quaternary Science Reviews, 28, 25-38. 
Moy, C.M., Dunbar, R.B., Moreno, P.I., Francois, J.-P., Villa-Martínez, R., Mucciarone, D. M., Guilderson, T.P., Garreaud, R.D., 2008, Isotopic evidence for hydrologic change related to the westerlies in SW Patagonia, Chile, during the last millennium: Quaternary Science Reviews, 27, 1335-1349.

Moy, C.M., Moreno, P.I., Dunbar, R.B., Kaplan, M.R., Francois, J.P., Villalba, R., Haberzettl, T., 2009, Climate change in Southern South America during the last two millennia, in $\mathrm{F}$. Vimeux et al., (eds.), Past Climate Variability in South America and Surrounding Regions, Developments in Paleoenvironmental Research, 14, 353-392.

Oliva, G., González, L., Rial, P., Livraghi, E., 2001, El ambiente de la Patagonia Austral, in Borrelli, P., Oliva, G. (eds.), Ganadería ovina sustentable en la Patagonia Austral, INTA Río Gallegos, 272 p.

Pisano, E., 1977, Fitogeografía de FuegoPatagonia Chilena. I.- Comunidades vegetales entre las latitudes $52^{\circ}$ y $56^{\circ}$ : Anales Instituto Patagonia, 8.

Roig, F.A., Anchorena, J., Dollenz, O., Faggi, A. M., Méndez, E., 1985, Las comunidades vegetales de la Transecta Botánica de la Patagonia Austral. Primera parte: la vegetación del área continental: Transecta Botánica de la Patagonia Austral, Boelcke, O., Moore, D.M., Roig, F.A., (eds.), 733 p.

Rumrich U., Lange-Bertalot, H., Rumrich, M., 2000, Iconographia Diatolmologica 9. Diatomeen der Anden von Venezuela bis Patagonien/Tierra del Fuego, in LangeBertalot, H. (ed) A.R.G. Gantner Verlag K. G. Germany, 1-673.

Simonsen, R., 1987, Atlas and catalogue of the diatom types of Friedrich Hustedt: Germany, Berlin, J. Cramer, I-III, 1-1741.
Sterken, M., Verleyen, E., Sabbe, K., Terryn, G., Charlet, F., Bertrand, S., Boës, X., Fagel, N., De Batist, M., Vyverman, W., 2008, Late Quaternary climatic changes in southern Chile, as recorded in a diatom sequence of Lago Puyehue (40 40' S): Journal of Paleolimnology, 39(2), 219-235.

Stine, S., 1994, Extreme and persistent drought in California and Patagonia during mediaeval time: Nature, 369(6481), 546-549.

Stockmarr, J., 1971, Tablets with spores used in absolute pollen analysis: Pollen et Spores 13, 615-621.

Stuiver, M., Reimer, P.J., 1993, Extended ${ }^{14} \mathrm{C}$ database and revised CALIB radiocarbon calibration program: Radiocarbon 35, 215-230.

Stuiver, M., Reimer, P.J., Reimer, R.W., 2005, CALIB 5.0. [WWW program and documentation].

Szeicz, J.M., Zeeb, B.A., Bennett, K.D., Smol, J.P., 1998, High-resolution palaeoecological analysis of recent disturbance in a southern Chilean Nothofagus forest: Journal of Paleolimnology, 20, 235-252.

Szeicz, J.M.,Haberle, S.G., Bennett, K.D., 2003, Dynamics of North Patagonian rainforest from fine-resolution pollen, charcoal and treering analysis, Chonos Archipielago, Southern Chile: Austral Ecology, 28, 413-422.

Villalba, R., 1994, Tree-Ring and Glacial Evidence for the Medieval Warm Epoch and the Little Ice Age in Southern South America: Climatic Change, 26, 183-197.

Zalasiewicz, J., Waters, C.N., do Sul, J.A.I., Corcoran, P.L., Barnosky, A.D., Cearreta, A., McNeill, J.R., 2016, The geological cycle of plastics and their use as a stratigraphic indicator of the Anthropocene: Anthropocene, 13, 4-17. 